\title{
Tetracycline-regulated secretion of human (pro)insulin following plasmid-mediated transfection of human muscle
}

\author{
Magdalene O Wilson, Kathleen T Scougall, Jarupa Ratanamart, Elizabeth A Mclntyre and \\ James A M Shaw
}

Diabetes Research Group, School of Clinical Medical Sciences, University of Newcastle upon Tyne, Framlington Place, Newcastle upon Tyne NE2 4HH, UK

(Requests for offprints should be addressed to Dr J A M Shaw; Email: jim.shaw@ncl.ac.uk)

\begin{abstract}
Long-term secretion of insulin by host muscle following transduction with an insulin gene construct offers the potential of gene therapy for diabetes without immunosuppression. Clinical implementation will be dependent on proof of principle in human tissue and a system for safely regulating basal insulin levels. Liposomal co-transfection with a tetracycline-responsive wild type human preproinsulin (pTRE-hppl1) or mutant construct (pTRE-hppl4), in which PC2 and PC3 cleavage sites were altered to form tetrabasic consensus sites for furin, together with pTet-off (coding for a transactivating protein) was evaluated in the $\mathrm{C} 2 \mathrm{C} 12$ mouse myoblast cell line and human myoblasts following establishment in primary culture. In the absence of tetracycline, (pro)insulin secretion in $\mathrm{C} 2 \mathrm{C} 12$ and human myoblasts transfected with tetracycline-responsive hppl1 and hppl4 constructs was comparable to that following transfection with equivalent constructs under the control of a constitutively active cytomegaloviral promoter. Percentage processing to mature insulin was $<5 \%$ in $\mathrm{C} 2 \mathrm{C} 12$ and human myoblasts transfected with pTet-off/pTRE-hppl1 but $>90 \%$ in $\mathrm{C} 2 \mathrm{C} 12$ cells and $45-60 \%$ in human myoblasts on transfection with pTet-off/pTRE-hppl4. Incremental dose-responsive suppression of proinsulin secretion was demonstrated in $\mathrm{C} 2 \mathrm{C} 12$ and human myoblasts expressing pTet-off/pTREhppl1 following incubation with tetracycline $(0-100 \mu \mathrm{g} / \mathrm{ml})$ for up to $72 \mathrm{~h}$. Reversibility was confirmed following tetracycline withdrawal. Dose-responsive tetracycline-inducible repression of mature insulin secretion was confirmed in C2C12 cells following transfection with pTet-off/pTRE-hppl4. Regulation of human proinsulin biosynthesis and secretion has been attained in vivo following plasmid-mediated gene transfer to rat skeletal muscle and oral tetracycline administration. In conclusion, processing to mature insulin has been confirmed following plasmid-mediated gene transfer to human muscle in addition to in vitro- and in vivo-regulated human proinsulin secretion employing the safe and well-tolerated antibiotic, tetracycline.
\end{abstract}

Journal of Molecular Endocrinology (2005) 34, 391-403

\section{Introduction}

There is conclusive evidence from prospective studies in Type 1 and Type 2 diabetes that long term sequelae can be prevented by tight glycaemic control (Diabetes Control and Complications Trial Research Group 1993, UK Prospective Diabetes Study Group 1998). Attainment of this with intensified conventional subcutaneous insulin therapy is associated with a three-fold increase in severe hypoglycaemia and requires considerable motivation from the diabetic individual in addition to costly health services input.

Transplantation of whole vascularised pancreas (Fiorina et al. 2001) and isolated islet cells (Ryan et al. 2002) has confirmed that insulin independence, nearnormal glucose levels and freedom from significant hypoglycaemia can be achieved through replacement of insulin-secreting cells. In addition to the surgical morbidity and potential mortality associated with these procedures and the need for lifelong treatment with potentially toxic immunosuppressant drugs, limited availability of human cadaveric tissue precludes wider implementation. For these reasons genetic engineering approaches to the treatment of both Type 1 and Type 2 diabetes mellitus are being explored (Shaw \& Docherty 2002).

Employment of skeletal muscle for in situ gene therapy has several unique advantages. These include uptake of plasmid following simple, highly patient-acceptable and cost-effective intramuscular injection avoiding the need for viral vectors (Wolff et al. 1992) and stable transgene incorporation into well-vascularised postmitotic muscle fibres enabling prolonged systemic secretion of human proteins at therapeutically active concentrations (Tripathy et al. 1996, Horton et al. 1999) without the need for immunosuppression. Risk of insertional oncogenesis is avoided through maintenance of the transgene as an extrachromosomal episome (Wolff et al. 1992). As muscle fibres are terminally differentiated, this approach is not complicated by hypoglycaemia due 
to ongoing cell proliferation following DNA uptake, a cause of hypoglycaemia in other non-neuroendocrine cell approaches to insulin gene therapy (Kawakami et al. 1992). There are currently 38 ongoing trials of plasmid-mediated muscle-targeted gene therapy for conditions including haemophilia without reported adverse effects (Gene Therapy Clinical Trials online database 2004).

We and others have demonstrated constitutive secretion of fully processed human insulin for up to 8 weeks following intramuscular injection of a preproinsulin plasmid mutated at PC2 and PC3 cleavage sites to form tetrabasic consensus recognition sites for the ubiquitous trans-Golgi network protease, furin (Martinenghi et al. 2002, Shaw et al. 2002). Glucoselowering without dangerous hypoglycaemia has been confirmed in normal and diabetic rodents. Efficiency of transgene uptake and hypoglycaemic effect can be augmented by in situ electroporation employing noninvasive electrodes externally placed on the muscle following plasmid injection (Martinenghi et al. 2002, Croze \& Prud'homme 2003).

Therapeutic applicability of this approach will be critically dependent on a mechanism for attaining regulated insulin secretion in addition to proof of concept in human muscle. We have previously reported regulated secretion of mature insulin employing the safe and well-tolerated antibiotic, tetracycline, in transfected non-neuroendocrine cells (Scougall et al. 2003) including rodent muscle established in primary culture (Scougall \& Shaw 2003).

In the current studies, we have confirmed that constitutive secretion of mature insulin can be attained in human muscle in vitro following transient plasmidmediated transfection with a furin-cleavable human preproinsulin construct. Down-regulation of proinsulin secretion in a dose-responsive and reversible manner by the addition of tetracycline following co-transfection with a tetracycline-repressible transactivator and an insulin plasmid containing a tetracycline-responsive element upstream of a minimal cytomegalovirus (CMV) promoter has been demonstrated. Regulated biosynthesis and systemic secretion of human proinsulin by transfected muscle fibres has been confirmed in vivo following intramuscular plasmid injection and oral tetracycline administration.

\section{Materials and methods}

\section{Insulin and reporter gene expression plasmids}

Sub-cloning of wild type human preproinsulin cDNA (hppIl) and a mutant construct (hppI4), in which the PC2 and PC3 dibasic cleavage sites have been mutated to form furin consensus cleavage sites, into pIRES-neo (Clontech, Palo Alto, CA, USA), pVR1012 (Vical Inc,
San Diego, CA, USA) and pTRE plasmid vectors has previously been described (Shaw et al. 2002, Scougall et al. 2003). The pTet-off plasmid encoding the tetracycline-repressible transactivator was obtained from Clontech. Comparative reporter gene plasmids in which a $\beta$-galactosidase cDNA has been sub-cloned in place of preproinsulin cDNA in pVR1012 and pTRE have previously been described (Scougall et al. 2003). Plasmids were amplified in $\mathrm{DH} 5 \alpha$ sub-cloning grade Escherichia coli, purified using the endotoxin-free method (Qiagen, Crawley, Sussex, UK), and redissolved in endotoxin-free water at a concentration of $1 \mu \mathrm{g} / \mu \mathrm{l}$. Purity was confirmed by spectrophotometry (A260/A280 ratio 1.75-2.0) with identity and absence of detectable RNA contamination confirmed by agarose gel electrophoresis following restriction digestion.

\section{Cell culture}

The C2C12 mouse muscle cell line was provided by Dr W Macfarlane, University of Newcastle, UK. Cells were cultured in Dulbecco's modified Eagle's medium (Sigma, UK) supplemented with $10 \%$ foetal bovine serum (FBS), $2 \mathrm{mmol} / \mathrm{l}$ glutamine, $100 \mathrm{U} / \mathrm{ml}$ penicillin $\mathrm{G}$ and $100 \mu \mathrm{g} / \mathrm{ml}$ streptomycin.

Human muscle biopsies were obtained from the vastus lateralis muscle of healthy adults without diabetes during hip surgery under general anaesthesia following informed written consent. Aneural muscle cultures were established as previously described (Blau \& Webster 1981, Halse et al. 1999). Myogenic enrichment was obtained by magnetic cell sorting. Harvested cells were suspended in separation buffer (phosphate buffered saline (PBS) containing $2 \mathrm{mM}$ EDTA and 5\% FBS) and incubated with a primary antibody, anti-CD56 (NCAM), recognising a muscle-specific cell surface antigen (Belles-Isles et al. 1993). After washing, the cell suspension was incubated with a goat anti-mouse secondary antibody linked to Mini-Mac magnetic microbeads (Miltenyi Biotec, Bisley, Surrey, UK) enabling retention on an $\mathrm{MS}^{+}$column housed within a magnetic field. Following elution in the absence of a magnetic field, cells were established in primary culture.

Human myoblasts were cultured in Ham's F10 medium (Invitrogen, Paisley, Strathclyde, UK) supplemented with 20\% FBS, $2 \%$ chick embryo extract (ICN, Costa Mesa, CA, USA), $100 \mathrm{U} / \mathrm{ml}$ penicillin $\mathrm{G}$ and $100 \mu \mathrm{g} / \mathrm{ml}$ streptomycin.

C2C12 and human myoblasts were passaged following trypsinisation at 60-80\% confluence and were maintained for a maximum of up to 6 passages.

For all studies, cells were cultured in a humidified incubator at $37^{\circ} \mathrm{C}$ in $5 \% \mathrm{CO}_{2}$ as a monolayer in 6-well plates pre-coated with Matrigel (Becton-Dickinson, Oxford, Oxon, UK) basement membrane matrix (Kleinman et al. 1982) diluted 1:25 in DMEM. In 
C2C12 and primary human myoblasts, DMEM supplemented with $2 \%$ horse serum and $2 \mathrm{mmol} / \mathrm{l}$ glutamine ('fusion medium') was used to induce myoblast fusion to form multi-nucleated myotubes.

Recombinant human proinsulin and insulin were obtained from Sigma-Aldrich (Poole, Dorset, UK).

\section{Immunocytochemistry}

Myoblasts plated onto Matrigel-coated coverslips in 6-well plates were fixed at $80-90 \%$ confluence with $100 \%$ methanol at $4{ }^{\circ} \mathrm{C}$ and washed with PBS. All subsequent steps were performed at room temperature. Non-specific antibody binding was blocked with $2 \%$ FBS in PBS (blocking buffer) for $1 \mathrm{~h}$ at $37^{\circ} \mathrm{C}$. Cells were incubated for $1 \mathrm{~h}$ at room temperature with mouse monoclonal anti-human desmin (D33, DAKO, DakoCytomation, Ely, Cambs, UK) at a 1 in 50 dilution in blocking buffer. Following three washes with blocking buffer, cells were incubated for $1 \mathrm{~h}$ at room temperature with anti-mouse $\operatorname{IgG}$ peroxidase conjugate (Sigma A3673) at a 1 in 100 dilution in blocking buffer. Following three PBS washes, cells were stained with Vector VIP substrate (Vector Laboratories, Peterborough, UK). Absence of staining was confirmed in negative controls in which blocking buffer was substituted for desmin primary antibody. After a further four PBS washes, coverslips were mounted in Vectashield aqueous mounting medium containing DAPI (4,6-diamidino-2-phenylindole) nuclear stain (Vector Laboratories) and visualised with bright field and fluorescence microscopy.

\section{Transfection and tetracycline addition}

C2C12 myoblasts were transfected at $60-80 \%$ confluence. Plasmid DNA $(1-3 \mu \mathrm{g})$ in $100 \mu \mathrm{l}$ DMEM and 2-25 $\mu$ l Lipofectamine (Invitrogen, Renfrew, UK) in $100 \mu \mathrm{l}$ DMEM were mixed and incubated for $15 \mathrm{~min}$ at room temperature. This was added to $0.8 \mathrm{ml}$ DMEM per well of cells with incubation at $37^{\circ} \mathrm{C}$ for $5 \mathrm{~h}$. DMEM (1 ml) supplemented with 20\% FBS was added with incubation for a further $17 \mathrm{~h}$ before substitution of standard growth medium. Optimal conditions for maximal (pro)insulin secretion were: $1 \mu \mathrm{g}$ pTRE-hppI1/ $1 \mu \mathrm{g}$ pTet-off/5 $\mu \mathrm{l}$ Lipofectamine, $1 \mu \mathrm{g}$ pTRE-hppI4/ $1 \mu \mathrm{g}$ pTet-off/5 $\mu \mathrm{l}$ Lipofectamine, $2 \mu \mathrm{g}$ pIRES-hppI4/ $10 \mu \mathrm{l}$ Lipofectamine, $2 \mu \mathrm{g}$ pVR1012-hppI4/10 $\mu \mathrm{l}$ Lipofectamine, and $3 \mu \mathrm{g}$ DNA/5 $\mu$ l Lipofectamine for pIRES-hppIl and pVR1012-hppI1. These conditions were employed for all reported transfection studies.

Human myoblasts were transfected at $80-90 \%$ confluence using $5 \mu \mathrm{g}$ DNA with $10 \mu \mathrm{l}$ Lipofectamine 2000 (Invitrogen) per well according to the manufacturer's guidelines substituting DMEM for insulincontaining Optimem (Invitrogen) serum-free medium.
These conditions were determined to be optimal for all plasmids.

Tetracycline (Sigma-Aldrich) was made up in $70 \%$ ethanol to a stock concentration of $10 \mathrm{mg} / \mathrm{ml}$. Further dilutions were performed in standard growth medium to give final concentrations ranging from $10 \mathrm{pg} / \mathrm{ml}$ to $100 \mu \mathrm{g} / \mathrm{ml}$. Tetracycline was added to cells $24 \mathrm{~h}$ after transfection.

\section{Protein quantification}

Intracellular protein was extracted in PBS from cell pellets by freeze-thaw ( 3 cycles: liquid nitrogen, $37^{\circ} \mathrm{C}$ water bath, vortex resuspension). Following the final cycle, extracts were centrifuged $(12000 \mathrm{~g})$ at $4{ }^{\circ} \mathrm{C}$ for $10 \mathrm{~min}$. The protein concentration of the supernatant was quantified by the Bradford method following the manufacturer's guidelines (Bio-Rad Laboratories, Hemel Hempstead, Herts, UK).

\section{Human (pro)insulin ELISA}

The medium was changed $24 \mathrm{~h}$ prior to sampling for ELISA. Intracellular protein was extracted and assayed at study termination. To determine human total proinsulin and ultrasensitive insulin, specific ELISA kits were purchased from Mercodia (Uppsala, Sweden) with intact proinsulin ELISA kits from DAKO being used. Assays were performed according to the manufacturers' instructions. Cross-reactivities for the human total proinsulin ELISA were $<0.03 \%$ for insulin, $<0.006 \%$ for C-peptide, 84\% for proinsulin des(64-65), 90\% for proinsulin split (65-66), 95\% for proinsulin des(31-32), and $95 \%$ for proinsulin split (32-33). Cross-reactivities for the ultrasensitive human insulin ELISA were $<0.01 \%$ for C-peptide, $<0.01 \%$ for proinsulin, $98 \%$ for proinsulin des(64-65), 56\% for proinsulin split $(65-66), \quad<0 \cdot 5 \%$ for proinsulin $\operatorname{des}(31-32)$, and $<0 \cdot 5 \%$ for proinsulin split (32-33). DAKO human intact proinsulin ELISA cross-reacts 66\% with 65-66 split proinsulin but not with insulin or 32-33 split proinsulin. All cross-reactivities refer to human peptides.

\section{In vivo gene transfer}

Specific Home Office approval was secured for all in vivo studies. Wistar rats aged five weeks and weighing 150-200 g were obtained from Charles River Laboratories, Margate, UK. Animals were divided into weight-matched groups with daily clinical evaluation. Left and right tibialis anterior muscles were injected perpendicularly percutaneously under isofluorane general anaesthesia with $100 \mu \mathrm{l}$ plasmid in normal saline ( $\mathrm{NaCl} 150 \mathrm{mmol} / \mathrm{l}$ ) employing a 25-gauge needle with $4 \mathrm{~mm}$ exposed beyond a protective plastic sheath. pVR1012- $\beta$ gal and pVR1012-hppI1 were employed at 
a concentration of $1 \mu \mathrm{g} / \mu \mathrm{l}$. pTRE- $\beta$-gal $(0.5 \mu \mathrm{g} / \mu \mathrm{l})$ or pTRE-hppIl $(0.5 \mu \mathrm{g} / \mu \mathrm{l})$ were combined with pTet-off $(0.5 \mu \mathrm{g} / \mu \mathrm{l})$ prior to injection. After each injection, muscle was electroporated (eight 20-ms $175-\mathrm{V} / \mathrm{cm}$ pulses at a frequency of $2 \mathrm{~Hz}$ ) transcutaneously employing a BTX830 square wave electroporator (Q-biogene, Nottingham, UK) and calliper electrodes applied to lateral and medial surfaces of tibialis anterior. Selected groups were treated with $1 \mathrm{mg} / \mathrm{ml}$ tetracycline added to drinking water for $72 \mathrm{~h}$ from days 4-7 post-plasmid injection. Samples $(2 \cdot 5 \mu \mathrm{l})$ for blood glucose assay and $200 \mu \mathrm{l}$ serum samples were obtained as previously described (Shaw et al. 2002). Muscle protein was extracted on study completion at day 7 post-plasmid injection by FastPrep120 (Q-biogene) homogenisation in buffer containing $10 \mathrm{mM}$ HEPES pH 7.9, $10 \mathrm{mM} \mathrm{KCl}$, $0 \cdot 1 \mathrm{mM}$ EDTA pH 8・0, 0.1 mM EGTA pH 8.0, $1 \mathrm{mM}$ dithiothreitol and protease inhibitors (Roche, UK). Serum and muscle proinsulin were determined by human-specific total proinsulin ELISA (Mercodia). $\beta$-galactosidase activity was quantified employing a $\beta$-galactosidase enzyme assay system (Promega, UK).

\section{Statistical analysis}

Results are reported as means \pm standard error of the mean (S.E.M.). Data were compared by one-way analysis of variance (ANOVA) with post-hoc assessment for least significant difference. $P<0.05$ was accepted as statistically significant.

\section{Results}

\section{Characterisation of $\mathrm{C} 2 \mathrm{C} 12$ and primary human muscle cells in culture}

Purity of myogenic origin in muscle cell cultures was confirmed by characteristic bipolar morphology and positive immunocytochemical staining for the muscle specific marker, desmin. Desmin expression was confirmed in $100 \%$ of C2C12 cells and in $>90 \%$ of human myoblasts. Formation of end-differentiated multinucleated myotubes on substitution of 'fusion medium' for $48 \mathrm{~h}$ at confluence was demonstrated in both $\mathrm{C} 2 \mathrm{C} 12$ and primary human muscle cells.

\section{Transfection of $\mathrm{C} 2 \mathrm{C} 12$ and human myoblasts with wild type human insulin plasmids}

In all studies, a two plasmid tetracycline regulatable system was evaluated. The pTRE-hppIl plasmid encodes wild type human preproinsulin cDNA downstream of a minimal CMV promoter and an upstream tetracycline-responsive element comprising seven copies of a 42 base pair tet operator (tetO) sequence derived from the bacterial tetracycline resistance gene. The second plasmid, pTet-off, encodes a tetracyclinerepressible transactivator (VP16/TetR) which binds to the tetracycline-responsive element and initiates transcription in the absence of tetracycline. Tetracycline inhibits binding and thus transgene transcription.

Comparative transfections were performed with plasmids in which the wild type preproinsulin transgene is constitutively expressed downstream of the immediate/early GMV promoter. The pIRES plasmid contains a synthetic intron enhancing mRNA stability in addition to an internal ribosomal entry sequence enabling co-expression of transgene, and a neomycin resistance gene on a single bicistronic mRNA, facilitating selection of stably transfected cells expressing the gene of interest (Rees et al. 1996). The pVR1012 plasmid has been empirically optimised for muscletargeted gene therapy (Hartikka et al. 1996).

Following optimisation of transfection conditions for each plasmid, comparative transfections of C2C12 and human myoblasts with tetracycline-responsive and constitutive wild type human insulin expression plasmids were performed. Proinsulin expression, biosynthesis, post-translational processing and secretion were determined by specific ELISAs. Timecourse studies demonstrated peak (pro)insulin secretion at $48 \mathrm{~h}$ posttransfection with all plasmids, persisting for 7-10 days in both $\mathrm{C} 2 \mathrm{C} 12$ and human muscle cells.

Transfection efficiency and transgene expression determined by total human (pro)insulin secretion in the absence of tetracycline with the two plasmid system was comparable to single plasmid transfections in $\mathrm{C} 2 \mathrm{G} 12$ (Fig. 1A) and human myoblasts (Fig. 1B). Absence of significant processing to mature insulin on expression of wild type human insulin plasmids in C2C12 and human myoblasts cells was confirmed by differential ELISA, with the majority of proinsulin remaining intact.

Constitutive secretion and absence of (pro)insulin storage in transfected $\mathrm{C} 2 \mathrm{C} 12$ and human muscle cells was demonstrated with total intracellular (pro)insulin levels (proinsulin+insulin) of less than $1 \mathrm{pmol} / \mathrm{l}$ and less than $1 \%$ of total (intracellular+extracellular (pro)insulin) in all studies.

Absence of extracellular or intracellular human proinsulin or insulin was confirmed in control transfections in both C2C12 and human muscle cells with null pVR1012, pIRES and pTRE constructs lacking the hppIl cDNA insert (levels in all studies being $<1 \mathrm{pmol} / \mathrm{l})$.

\section{Transfection of $\mathrm{C2C} 12$ and human myoblasts with mutant human insulin plasmids}

Following optimisation of transfection conditions for each plasmid, comparative transfections of $\mathrm{C} 2 \mathrm{C} 12$ and 

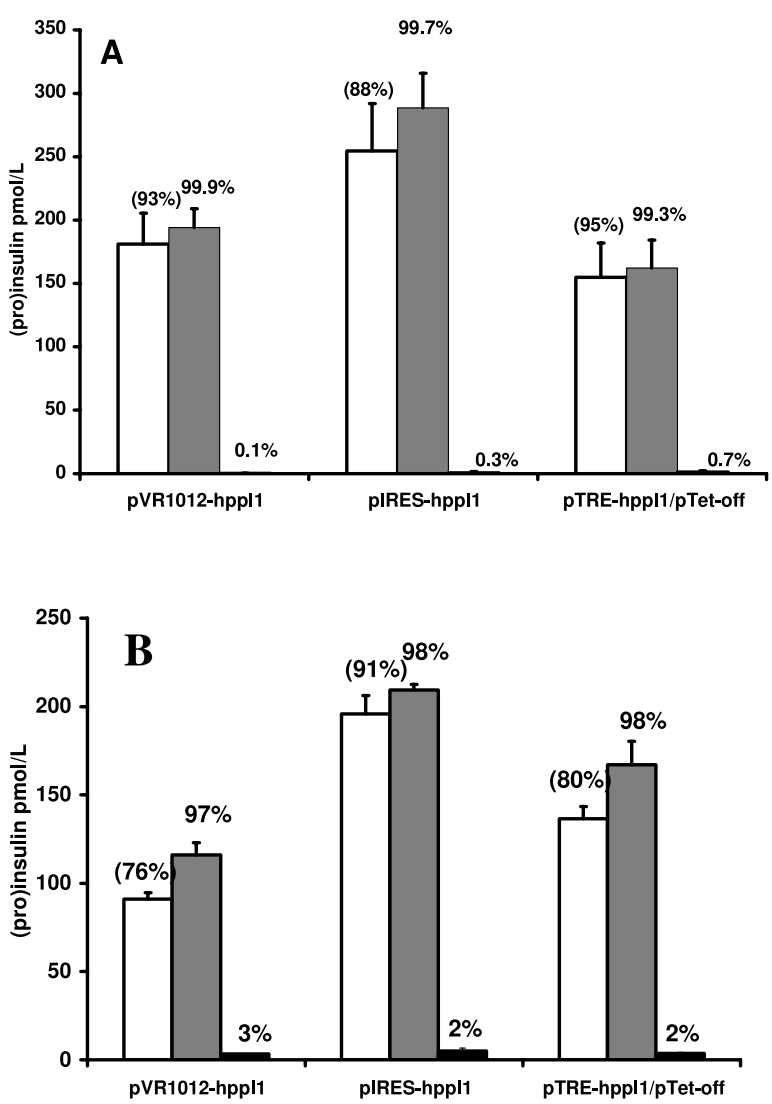

Figure 1 Human (pro)insulin processing and secretion in $(A)$ $\mathrm{C} 2 \mathrm{C} 12$ and $(\mathrm{B})$ human myoblasts at $48 \mathrm{~h}$ post-transfection with wild type insulin constructs determined by ELISA for intact proinsulin (open bars: in brackets refers to percentage of total proinsulin which is intact), total proinsulin including partially processed intermediates (grey bars: refers to proinsulin percentage of total proinsulin+insulin) and insulin (solid bars: refers to insulin percentage of total proinsulin+insulin). Samples were assayed in duplicate (means \pm S.E.M.; $n=4$ ). Results are representative of four repeated studies.

human myoblasts with tetracycline-responsive and constitutive mutant human insulin expression plasmids were performed. Peak (pro)insulin secretion at $48 \mathrm{~h}$ post-transfection was demonstrated with all plasmids, persisting for 7-10 days in both $\mathrm{C} 2 \mathrm{C} 12$ and human muscle cells.

Transfection efficiency and transgene expression with the two plasmid system in the absence of tetracycline was again comparable to single plasmid transfections in C2C12 (Fig. 2A) and human myoblasts (Fig. 2B). Significant post-translational proinsulin processing was confirmed with the furin-cleavable mutant plasmids. Less than $2 \%$ of total proinsulin remained intact. Greater than $90 \%$ of overall (pro)insulin was fully processed to insulin in transfected C2C12 myoblasts with $45-60 \%$ processing to mature insulin in human myoblasts.
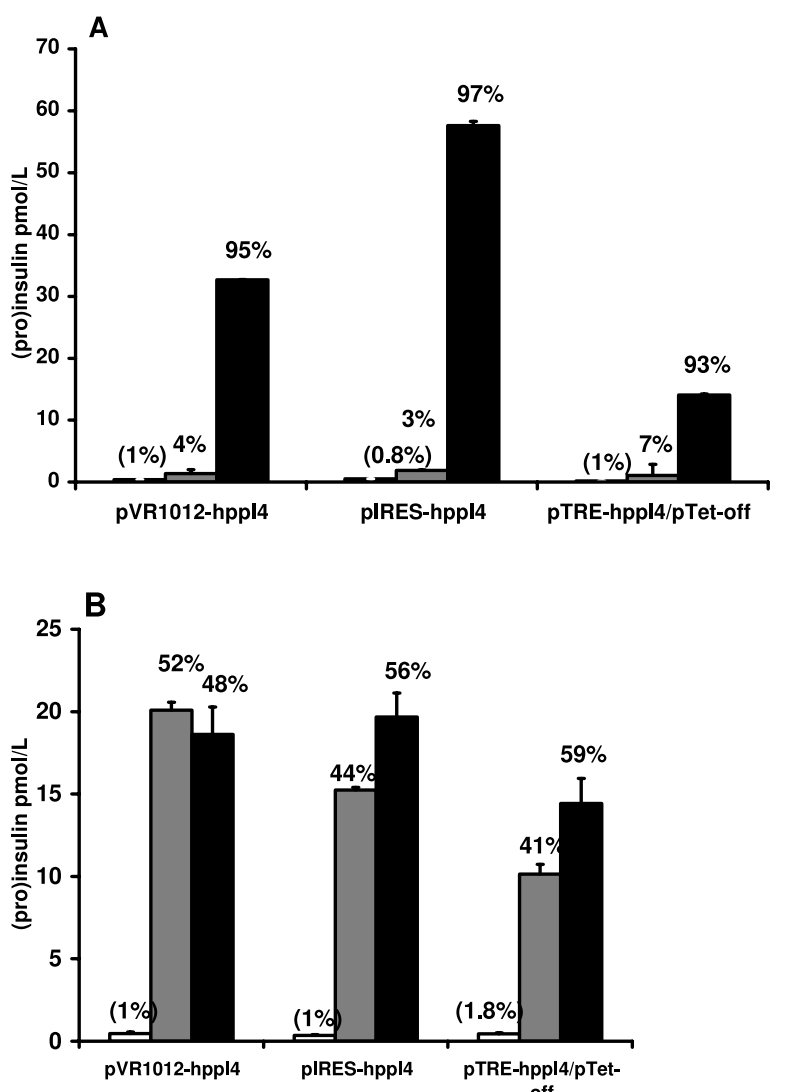

Figure 2 Human (pro)insulin processing and secretion in (A) $\mathrm{C} 2 \mathrm{C} 12$ and $(\mathrm{B})$ human myoblasts at $48 \mathrm{~h}$ post-transfection with furin-cleavable insulin constructs determined by ELISA for intact proinsulin (open bars: in brackets refers to percentage of total proinsulin which is intact), total proinsulin including partially processed intermediates (grey bars: refers to proinsulin percentage of total proinsulin+insulin), and insulin (solid bars: refers to insulin percentage of total proinsulin+insulin). Samples were assayed in duplicate (means \pm S.E.M.; $n=4$ ). Results are representative of four repeated studies.

Constitutive secretion and absence of (pro)insulin storage in $\mathrm{C} 2 \mathrm{C} 12$ and human muscle cells expressing the mutant insulin transgene was confirmed with intracellular (pro)insulin levels of less than $2 \mathrm{pmol} / \mathrm{l}$ and less than $5 \%$ of total (intracellular+extracellular concentration) in all studies.

\section{Proinsulin and insulin degradation/metabolism in C2C12 and human myoblasts}

Human recombinant proinsulin and insulin were diluted in complete medium and added to $\mathrm{C} 2 \mathrm{C} 12$ cells, primary human myoblasts or wells without cells and incubated $\left(5 \% \mathrm{CO}_{2}, 37^{\circ} \mathrm{C}\right)$ for $24 \mathrm{~h}$ with the remainder being stored at $-20^{\circ} \mathrm{C}$.

There was no evidence of significant degradation of 

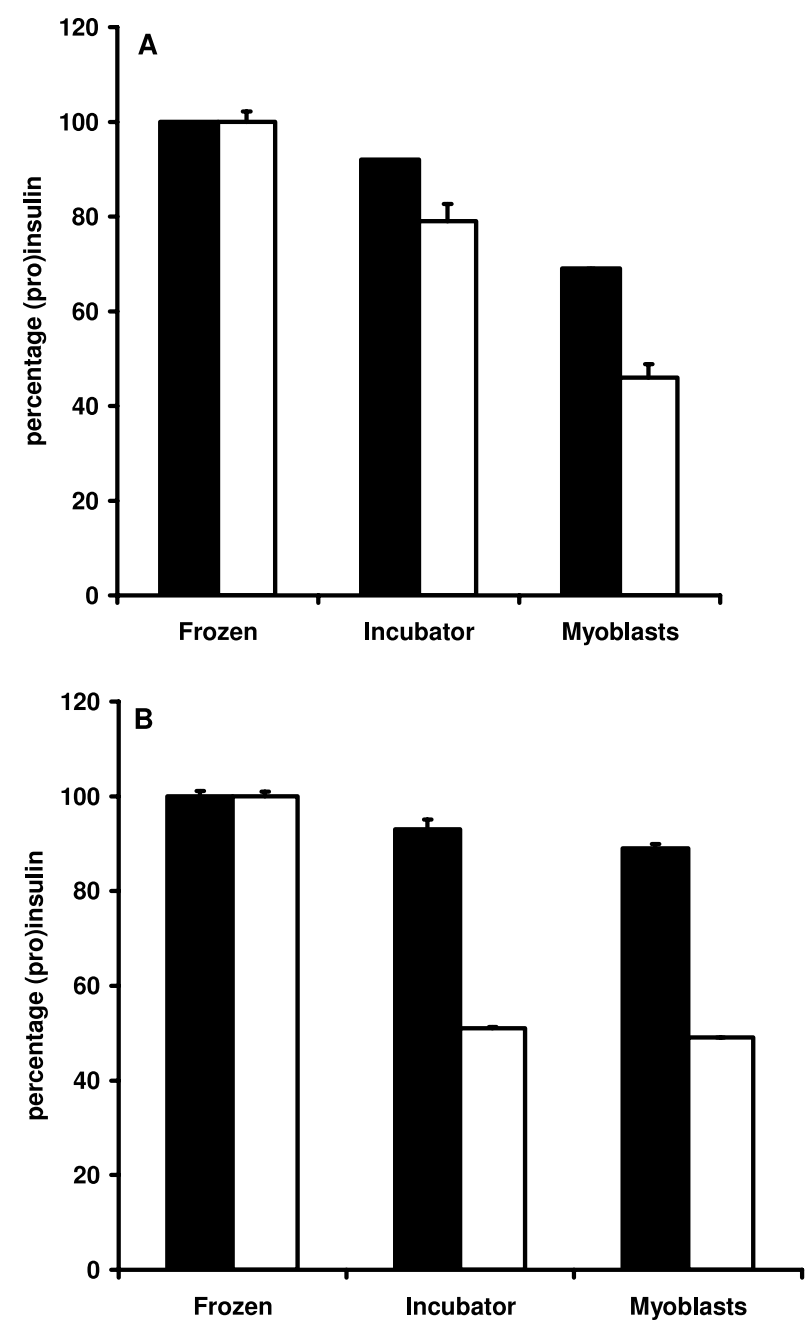

Figure 3 Differential degradation/metabolism of proinsulin and insulin in $\mathrm{C} 2 \mathrm{C} 12 /$ human myoblasts cultures. (A) C2C12 and (B) human myoblast culture medium was spiked with human recombinant proinsulin (solid bars) or insulin (open bars) both at a concentration of $1 \mathrm{ng} / \mathrm{ml}$. Aliquots $(2 \mathrm{ml})$ were stored at $-20^{\circ} \mathrm{C}$ (frozen), added to 6 -well plates without cells and incubated for $24 \mathrm{~h}$ in $5 \% \mathrm{CO}_{2}$ at $37^{\circ} \mathrm{C}$ (incubator), or added to $\mathrm{C} 2 \mathrm{C} 12$ cells at $80 \%$ confluence with incubation for $24 \mathrm{~h}$ (myoblasts) prior to total proinsulin (solid bars) or ultrasensitive insulin (open bars) ELISA. Results are shown as a percentage of the level detected in frozen medium (means \pm S.E.M.; $n=3$ ). Results are representative of 3 repeated studies.

proinsulin in $\mathrm{C} 2 \mathrm{C} 12$ medium at $37{ }^{\circ} \mathrm{C}$ in the absence of cells, with the detected level being $92 \%$ of that in medium stored at $-20^{\circ} \mathrm{C}$. The proinsulin level was reduced to $69 \%$ of that in stored medium in the presence of C2C12 myoblasts (Fig. 3A). Insulin levels decreased to $79 \%$ of that in stored medium following incubation for $24 \mathrm{~h}$ at $37^{\circ} \mathrm{C}$ in the absence of cells, and decreased further to $46 \%$ in the presence of C2C12 cells (Fig. 3A).

There was no evidence of significant degradation of proinsulin in human myoblast medium incubated at $37^{\circ} \mathrm{C}\left(93 \%\right.$ of that in medium stored at $\left.-20{ }^{\circ} \mathrm{C}\right)$ or metabolism by human myoblasts $(89 \%$ of that in medium stored at $-20^{\circ} \mathrm{C}$ ) (Fig. 3B). Insulin levels decreased significantly to $51 \%$ of that in stored medium following incubation for $24 \mathrm{~h}$ at $37^{\circ} \mathrm{C}$ in the absence of cells, and decreased further to $49 \%$ in the presence of human myoblasts (Fig. 3B).

There was no evidence for false positive crossreactivity of degradation products with specific proinsulin or insulin ELISA, proinsulin levels remaining insignificant in medium spiked with insulin, and insulin levels remaining insignificant in medium spiked with proinsulin.

\section{Tetracycline-regulated proinsulin secretion in transiently transfected $\mathrm{C} 2 \mathrm{C} 12$ and human myoblasts}

The potential for regulation of (pro)insulin secretion by tetracycline was evaluated in vitro in $\mathrm{C} 2 \mathrm{C} 12$ and human myoblasts. Following transient transfection with the tetracycline-responsive wild type human insulin construct (pTRE-hppI1) or the tetracycline-repressible transactivator plasmid (pTet-off) individually, no significant human (pro)insulin secretion was detected by differential ELISA in C2C12 or human myoblasts.

On co-transfection of C2C12 myoblasts with pTREhppIl and pTet-off (Fig. 4A) proinsulin secretion in the absence of tetracycline over the first $24 \mathrm{~h}$ was 160-163 pmol/l, with no significant differences between groups (ANOVA, $P>0 \cdot 05$ ). Addition of tetracycline over a wide range of concentrations $(10 \mathrm{pg} / \mathrm{ml}-100 \mu \mathrm{g} / \mathrm{ml})$ and incubation for $24 \mathrm{~h}$ resulted in a dose-responsive reduction in proinsulin secretion (24-h tetracycline incubation: $0 \mathrm{pg} / \mathrm{ml}, 100 \% ; 10 \mathrm{pg} / \mathrm{ml}, 92 \% ; 100 \mathrm{pg} / \mathrm{ml}$, $81 \% ; 10 \mathrm{ng} / \mathrm{ml}, 73 \% ; 1 \mu \mathrm{g} / \mathrm{ml}, 69 \% ; 100 \mu \mathrm{g} / \mathrm{ml}, 63 \%)$. This was reduced further over the next $24 \mathrm{~h}(48-\mathrm{h}$ tetracycline incubation: $0 \mathrm{pg} / \mathrm{ml}, 100 \% ; 10 \mathrm{pg} / \mathrm{ml}, 90 \%$; $100 \mathrm{pg} / \mathrm{ml}, \quad 45 \% ; 10 \mathrm{ng} / \mathrm{ml}, \quad 23 \% ; 1 \mu \mathrm{g} / \mathrm{ml}, \quad 18 \%$; $100 \mu \mathrm{g} / \mathrm{ml}, 7 \%$ ). Dose-responsive tetracycline regulation of proinsulin secretion was maintained over a further $24 \mathrm{~h}$ incubation (72-h tetracycline incubation: $0 \mathrm{pg} / \mathrm{ml}$, $100 \% ; 10 \mathrm{pg} / \mathrm{ml}, 82 \% ; 100 \mathrm{pg} / \mathrm{ml}, 46 \% ; 10 \mathrm{ng} / \mathrm{ml}$, $40 \% ; 1 \mu \mathrm{g} / \mathrm{ml}, 25 \% ; 100 \mu \mathrm{g} / \mathrm{ml}, 13 \%$ ).

On co-transfection of human myoblasts with pTREhppIl and pTet-off (Fig. 4B) proinsulin secretion in the absence of tetracycline over the first $24 \mathrm{~h}$ was 69-81 pmol/1, with no significant differences between groups (ANOVA, $P>0 \cdot 05$ ). Addition of tetracycline over a wide range of concentrations $(10 \mathrm{pg} / \mathrm{ml}-1 \mu \mathrm{g} / \mathrm{ml})$ and incubation for $24 \mathrm{~h}$ resulted in dose-responsive reduction in proinsulin secretion (24-h tetracycline incubation: $0 \mathrm{pg} / \mathrm{ml}, 100 \% ; 10 \mathrm{pg} / \mathrm{ml}, 75 \% ; 100 \mathrm{pg} / \mathrm{ml}$, $63 \% ; 10 \mathrm{ng} / \mathrm{ml}, \quad 41 \% ; 1 \mu \mathrm{g} / \mathrm{ml}, 32 \%)$. This was maintained over the next $24 \mathrm{~h}$ (48-h tetracycline incubation: $0 \mathrm{pg} / \mathrm{ml}, 100 \% ; 10 \mathrm{pg} / \mathrm{ml}, 82 \% ; 100 \mathrm{pg} / \mathrm{ml}$, 

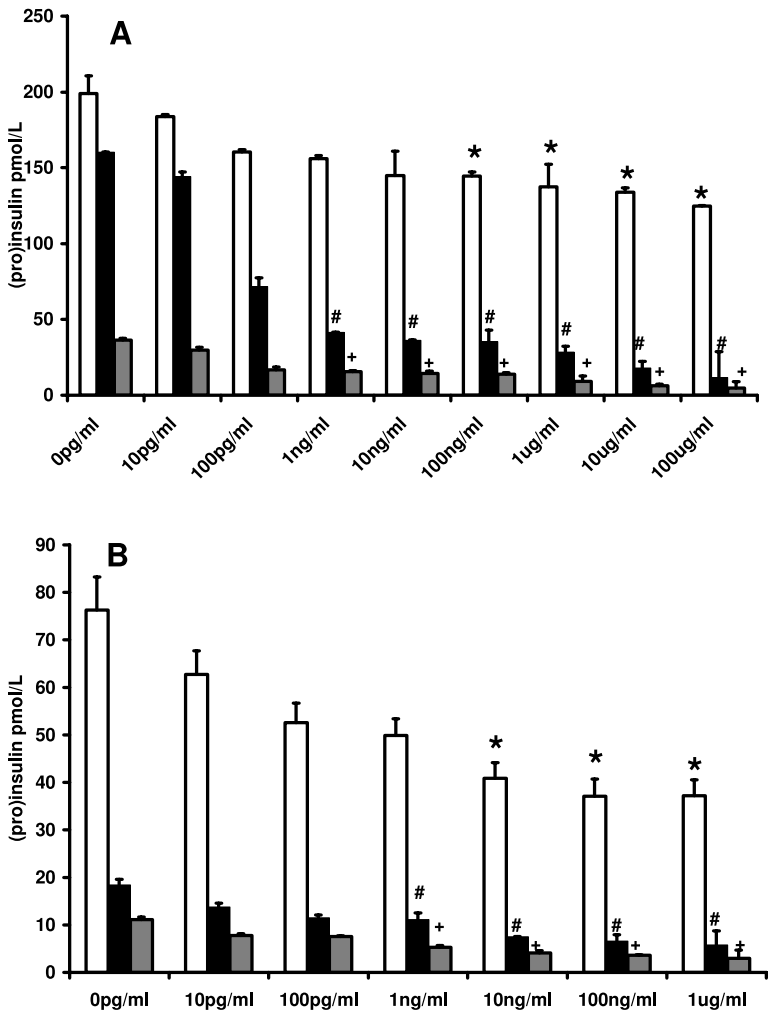

Figure 4 Tetracycline regulated proinsulin secretion in (A) C2C12 and (B) human myoblasts following co-transfection with pTRE-hppl1 and pTet-off. Over the first $24 \mathrm{~h}$ post-transfection in the absence of tetracycline, equivalent proinsulin secretion was seen in all groups. The medium was harvested and replaced with $0-100 \mu \mathrm{g} / \mathrm{ml}$ tetracycline at $24-\mathrm{h}$ intervals thereafter. Proinsulin levels in the medium are shown over the subsequent $24 \mathrm{~h}$ (open bars), $48 \mathrm{~h}$ (solid bars) and $72 \mathrm{~h}$ (grey bars) (means \pm S.E.M.; $n=3$; ${ }^{*} P<0.05$ vs tetracycline untreated over $24 \mathrm{~h}$; $\# P<0.05$ vs tetracycline untreated over $48 \mathrm{~h}$; $+P<0.05$ vs tetracycline untreated over $72 \mathrm{~h}$ ). Results are representative of four repeated studies.

$69 \% ; \quad 10 \mathrm{ng} / \mathrm{ml}, \quad 53 \% ; \quad 1 \mu \mathrm{g} / \mathrm{ml}, \quad 49 \%)$. Maximal dose-responsive tetracycline-induced repression of proinsulin secretion was seen after a further $24 \mathrm{~h}(72-\mathrm{h}$ tetracycline incubation: $0 \mathrm{pg} / \mathrm{ml}, 100 \% ; 10 \mathrm{pg} / \mathrm{ml}, 70 \%$; $100 \mathrm{pg} / \mathrm{ml}, 68 \% ; 10 \mathrm{ng} / \mathrm{ml}, 37 \% ; 1 \mu \mathrm{g} / \mathrm{ml}, 27 \%)$.

Absence of any effect of tetracycline on proinsulin secretion following transfection with the wild type human insulin transgene under the control of a constitutively active CMV promoter was demonstrated. At $48 \mathrm{~h}$ post transfection of $\mathrm{C} 2 \mathrm{C} 12$ myoblasts with pIRES-hppIl, there were no significant differences in proinsulin secretion following 24-h incubation with tetracycline in the range of 0 to $1 \mu \mathrm{g} / \mathrm{ml}(n=3 ; P>0 \cdot 05$, ANOVA).

Tetracycline addition was not associated with cell death, growth inhibition or proliferation following transfection of $\mathrm{C} 2 \mathrm{C} 12$ or human myoblasts with
pTRE-hppI1/pTet-off. Cells were harvested and intracellular lysates extracted at study completion at $96 \mathrm{~h}$ following transfection. There were no significant differences in intracellular protein concentrations between groups incubated in the absence of tetracycline and at any tetracycline concentration up to $1 \mu \mathrm{g} / \mathrm{ml}$ $(P>0.05$, ANOVA). Intracellular protein concentration was significantly reduced to $73 \%$ of that in the absence of tetracycline in C2C12 cells following pTRE-hppI1/ pTet-off transfection and 72-h incubation in the presence of tetracycline at concentrations of $10 \mu \mathrm{g} / \mathrm{ml}$ and $100 \mu \mathrm{g} / \mathrm{ml}$.

Proinsulin to insulin processing was not influenced by tetracycline treatment, with mature insulin concentration remaining $<1 \mathrm{pmol} / 1$ and constituting $<5 \%$ of overall (pro)insulin at all time points in all studies in both C2C12 and human myoblasts. Tetracycline addition was not associated with intracellular accumulation of (pro)insulin, intracellular levels remaining $<2 \mathrm{pmol} / \mathrm{l}$ at all tetracycline concentrations.

\section{Reversibility of tetracycline-induced repression of proinsulin transcription and secretion in transfected muscle cells}

The potential for reversing tetracycline-induced inhibition of proinsulin secretion in transfected muscle was evaluated. Addition of $0 \cdot 1 \mu \mathrm{g} / \mathrm{ml}$ tetracycline at $24 \mathrm{~h}$ post-transfection of human myoblasts with pTRE-hppI 1 and pTet-off reduced proinsulin secretion to $19 \%$ of that seen in the absence of tetracycline over the subsequent $72 \mathrm{~h}$ (Fig. 5). Following tetracycline withdrawal for a further $72 \mathrm{~h}$, proinsulin secretion was restored to $92 \%$ of that in untreated cells. In wells treated with $0 \cdot 1 \mu \mathrm{g} / \mathrm{ml}$ tetracycline from days $1-5$, proinsulin secretion decreased to $10 \%$ at $72 \mathrm{~h}$ and remained at $<15 \%$ of levels in untreated cells for the remainder of the study.

\section{Tetracycline-regulated secretion of fully processed human insulin in transiently transfected muscle in vitro}

The potential for tetracycline regulation of fully processed human insulin secretion in C2C12 myoblasts was evaluated in vitro. Following transient transfection with the tetracycline-responsive mutant human insulin construct (pTRE-hppI4) or the tetracycline-repressible transactivator plasmid (pTet-off) individually, no significant human (pro)insulin secretion was detected by differential ELISA in C2C12 or human myoblasts.

On co-transfection of C2C12 myoblasts with pTREhppI4 and pTet-off (Fig. 6) mean insulin secretion in the absence of tetracycline over the first $24 \mathrm{~h}$ was $15 \mathrm{pmol} / \mathrm{l}$ with no significant differences between groups (ANOVA, $P>0 \cdot 05$ ). Addition of tetracycline over a wide range of 


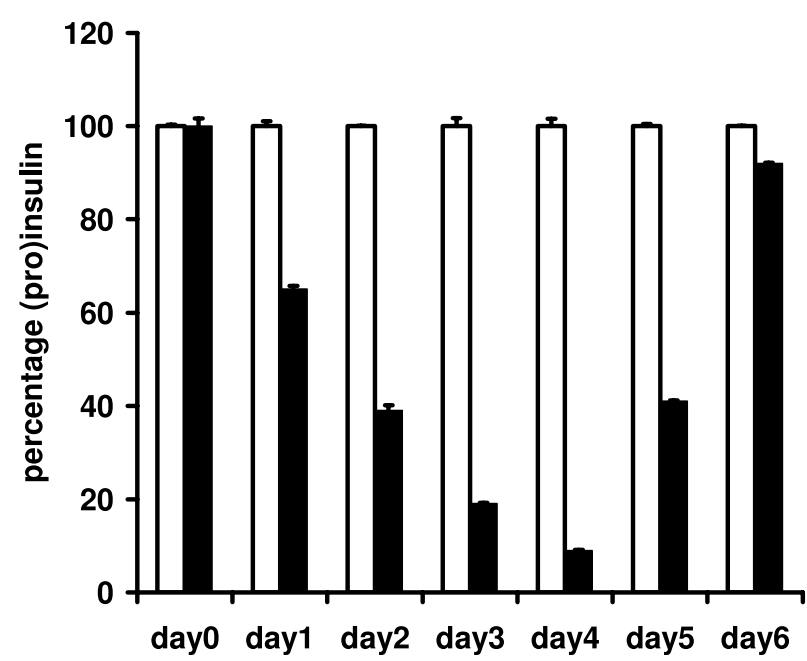

Figure 5 Reversal of tetracycline inhibition of proinsulin secretion in human myoblasts co-transfected with pTRE-hppl1 and pTet-off. Proinsulin secretion following addition of $0.1 \mu \mathrm{g} / \mathrm{ml}$ tetracycline to culture medium at $24 \mathrm{~h}$ post-transfection for $72 \mathrm{~h}$ (days $1,2,3$ ) and withdrawal for the subsequent $72 \mathrm{~h}$ (days 4 , 5,6 ) is shown (solid bars) as a percentage of that in cells cultured in the absence of tetracycline throughout (open bars). Medium was replaced every $24 \mathrm{~h}$ and samples were assayed in duplicate (means \pm S.E.M.; $n=3$ ).

concentrations $(10 \mathrm{pg} / \mathrm{ml}-100 \mu \mathrm{g} / \mathrm{ml})$ and incubation for $24 \mathrm{~h}$ resulted in dose-responsive reduction in proinsulin secretion (24-h tetracycline incubation: $0 \mathrm{pg} / \mathrm{ml}, \quad 100 \% ; 10 \mathrm{pg} / \mathrm{ml}, \quad 84 \% ; 100 \mathrm{pg} / \mathrm{ml}, \quad 70 \%$; $10 \mathrm{ng} / \mathrm{ml}, 61 \% ; 1 \mu \mathrm{g} / \mathrm{ml}, 55 \% ; 100 \mu \mathrm{g} / \mathrm{ml}, 31 \%)$. This was reduced further over the next $24 \mathrm{~h}$ (48-h tetracycline

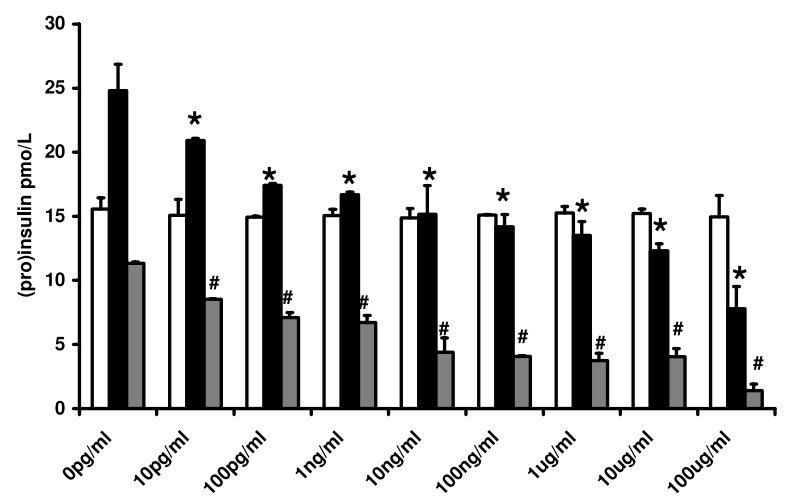

Figure 6 Tetracycline-regulated proinsulin secretion in $\mathrm{C} 2 \mathrm{C} 12$ myoblasts following co-transfection with pTRE-hppl4 and pTet-off. Over the first $24 \mathrm{~h}$ post-transfection in the absence of tetracycline, equivalent proinsulin secretion was seen in all groups (open bars). The medium was harvested and replaced with $0-100 \mu \mathrm{g} / \mathrm{ml}$ tetracycline at $24 \mathrm{~h}$ intervals thereafter. Proinsulin levels in the medium are shown over the subsequent $24 \mathrm{~h}$ (solid bars) and $48 \mathrm{~h}$ (grey bars) (means \pm S.E.M.; $n=3$; ${ }^{*} P<0.05$ vs tetracycline untreated over $24 \mathrm{~h} ; \# P<0.05$ vs tetracycline untreated over $48 \mathrm{~h}$ ). Results are representative of four repeated studies. incubation: $0 \mathrm{pg} / \mathrm{ml}, 100 \% ; 10 \mathrm{pg} / \mathrm{ml}, 75 \% ; 100 \mathrm{pg} / \mathrm{ml}$, $63 \% ; 10 \mathrm{ng} / \mathrm{ml}, 39 \% ; 1 \mu \mathrm{g} / \mathrm{ml}, 33 \% ; 100 \mu \mathrm{g} / \mathrm{ml}, 12 \%)$.

Tetracycline addition was not associated with cell death, growth inhibition or proliferation following transfection of C2C12 myoblasts with pTRE-hppI4/ pTet-off. Cells were harvested and intracellular lysates extracted at study completion at $96 \mathrm{~h}$ following transfection. There were no significant differences in intracellular protein concentrations between groups incubated in the absence of tetracycline or at any tetracycline concentration up to $1 \mu \mathrm{g} / \mathrm{ml} \quad(P>0 \cdot 05$, ANOVA). Intracellular protein concentration was significantly reduced to $73 \%$ of that in the absence of tetracycline at tetracycline concentrations of $10 \mu \mathrm{g} / \mathrm{ml}$ and $100 \mu \mathrm{g} / \mathrm{ml}$.

Proinsulin to insulin processing was not influenced by tetracycline treatment, with proinsulin concentration remaining $<1 \mathrm{pmol} / 1$ and constituting $<5 \%$ of overall (pro)insulin at all time points in all studies. Tetracycline addition was not associated with intracellular accumulation of (pro)insulin, intracellular levels remaining $<2 \mathrm{pmol} / \mathrm{l}$ at all tetracycline concentrations.

\section{Tetracycline-regulated reporter gene expression and proinsulin secretion following plasmid-mediated muscle-targeted in vivo gene transfer.}

Proof of principle for transgene expression following in situ plasmid-mediated muscle-targeted gene transfer was demonstrated in normal rats. Percutaneous injection and electroporation were tolerated well without adverse effects.

$\beta$-galactosidase activity in tibialis anterior muscles harvested at 7 days post-plasmid injection was confirmed following injection with pTRE- $\beta$ gal combined with pTet-off in the absence of tetracycline treatment (Fig. 7A). Activity was comparable with that attained following injection with the constitutively expressed reporter gene (pVR1012- $\beta$ gal). Mean total numbers of $\beta$-galactosidase fibres per muscle determined in stained cross-sections were 820 on pVR1012- $\beta$ gal injection and 730 on pTRE- $\beta$-gal/pTet-off injection $(n=3)$. The potential for tetracycline regulation in vivo was demonstrated by reduced $\beta$-galactosidase activity on following supplementation of water with $1 \mathrm{mg} / \mathrm{ml}$ tetracycline for $72 \mathrm{~h}$.

Proinsulin biosynthesis in tibialis anterior muscles harvested at 7 days post-plasmid injection was confirmed by human-specific ELISA following injection with pTRE-hppIl combined with pTet-off in the absence of tetracycline treatment (Fig. 7B). Synthesis of human proinsulin was significantly greater than in muscles injected with the constitutively expressed wild type preproinsulin plasmid (pVR1012-hppI1). Localisation of transgene expression to individual muscle fibres was confirmed by (pro)insulin immunohistochemistry. The 
potential for tetracycline regulation in vivo was demonstrated by reduced proinsulin biosynthesis following supplementation of water with $1 \mathrm{mg} / \mathrm{ml}$ tetracycline for $72 \mathrm{~h}$.

Systemic secretion of human proinsulin has been confirmed following injection with pTRE-hppIl combined with pTet-off in the absence of tetracycline treatment (Fig. 7C). Serum human proinsulin at 4 and 7 days post-plasmid injection was higher than in rats injected with the constitutively expressed wild type preproinsulin plasmid (pVR1012-hppI1). Tetracycline regulation was demonstrated by significantly reduced levels of circulating human proinsulin following supplementation of water with $1 \mathrm{mg} / \mathrm{ml}$ tetracycline for $72 \mathrm{~h}$.

Normal glucose levels $(4 \cdot 5-7 \cdot 5 \mathrm{mmol} / \mathrm{l})$ were maintained in all studies confirming the absence of significant hypoglycaemia. Animals remained well throughout with weights remaining comparable in all groups.

\section{Discussion}

The potential for long-term restoration of constitutive insulin secretion following plasmid-mediated in situ gene transfer to skeletal muscle has been described previously by several groups employing mouse, rat and human insulin constructs mutated at PG2 and PC3 sites to enable furin cleavage.

The mutant human insulin construct, hppI4, was generated from the full length human preproinsulin cDNA (hppI1) by site-directed mutagenesis of PC2 and PC3 cleavage sites to form consensus tetrabasic sites for furin cleavage (Arg-Lys-Arg-Arg). This results in substitution of two basic amino acids at both terminals of the 31 amino acid C-peptide. Furin cleavage enables secretion of fully processed unmodified human insulin, in contrast to alternative constructs (Simonson et al. 1996) which introduce a lysine to arginine point mutation of unknown function or mitogenicity at the penultimate $\mathrm{B}$ chain amino acid (B29) in mature insulin. The $\mathrm{B} 10$ histidine to aspartic acid substitution, which has been shown to enhance insulin secretion (Simonson et al. 1996) and hypoglycaemic efficacy with rat (Abai et al. 1999) and human (Croze \& Prud'homme 2003) proinsulin constructs was also avoided due to concerns surrounding its mitogenic potential, evidenced by induction of mammary tumour formation in susceptible rats, leading to withdrawal from clinical trials. Constitutive insulin secretion for up to 5 weeks, resulting in glucose lowering without hypoglycaemia, has been confirmed in rats following intramuscular hppI 4 plasmid injection (Shaw et al. 2002).

Demonstration of constitutive human proinsulin secretion following plasmid-mediated transfection of human skeletal muscle cells established in primary culture has not previously been reported. Comparable (pro)insulin secretion was attained on transient transfection with wild type human preproinsulin transgenes downstream of constitutively active CMV promoters and a construct under the control of a tetracycline responsive element upstream of a minimal CMV promoter necessitating co-transfection with a second plasmid encoding a tetracycline-repressible transactivator for transgene transcription leading to therapeutic protein biosynthesis and secretion.

Secretion of fully processed unmodified human insulin has been demonstrated following transfection with furin-cleavable hppI 4 constructs. Processing to mature insulin in transfections with the tetracycline-regulatable hppI4 plasmid was comparable to that seen with constitutive hppI4 plasmids.

It has previously been suggested that co-transfection with a plasmid expressing furin is necessary to achieve sufficient processing to mature insulin for therapeutic efficacy of muscle-targeted gene therapy for diabetes (Kon et al. 1999). We have previously reported 45-60\% processing to insulin on transient transfection of primary rat myoblasts with hppI4 without significant enhancement on co-transfection with a furin plasmid driven by a constitutive GMV promoter (Shaw et al. 2002). In the current studies, greater than $90 \%$ processing to insulin was confirmed in hppI4-transfected C2C12 myoblasts, consistent with previous reports (Yamasaki et al. 1999), and $45-60 \%$ processing was attained in primary human myoblasts. Differential ELISA demonstrated that less than $2 \%$ of total proinsulin remained intact in $\mathrm{C} 2 \mathrm{C} 12$ or human myoblasts following hppI4 transfection.

A significant reduction in overall levels of (pro)insulin detected in the medium over a 24-h incubation following transfection with hppI4 in comparison with hppIl constructs was demonstrated in both C2C12 and human myoblasts. This is a consistent finding in all publications comparing wild type with furin-cleavable insulin constructs (Hay \& Docherty 2003). A secretory defect is precluded by the very low levels of intracellular (pro)insulin in wild type and mutant transfections. Comparable mRNA expression by Northern blotting (Scougall \& Shaw 2003) and mRNA stability assay (Hay \& Docherty 2003) in wild type and mutant transfections has been confirmed. At least partial explanation is provided by greater degradation in serum and metabolism by myoblasts of insulin relative to proinsulin demonstrated in primary rat myoblasts (Scougall \& Shaw 2003) and confirmed in the current studies in C2C12 and human myoblasts. This argues also for greater than $45-60 \%$ processing to insulin in transfected human myoblasts when insulin degradation and metabolism over the 24-h incubation is taken into account. This is supported by fivefold greater C-peptide than insulin concentrations in the medium over a 24-h period in transfected C2G12 myotubes as opposed to the equimolar amounts envisaged (Martinenghi et al. 2002). 

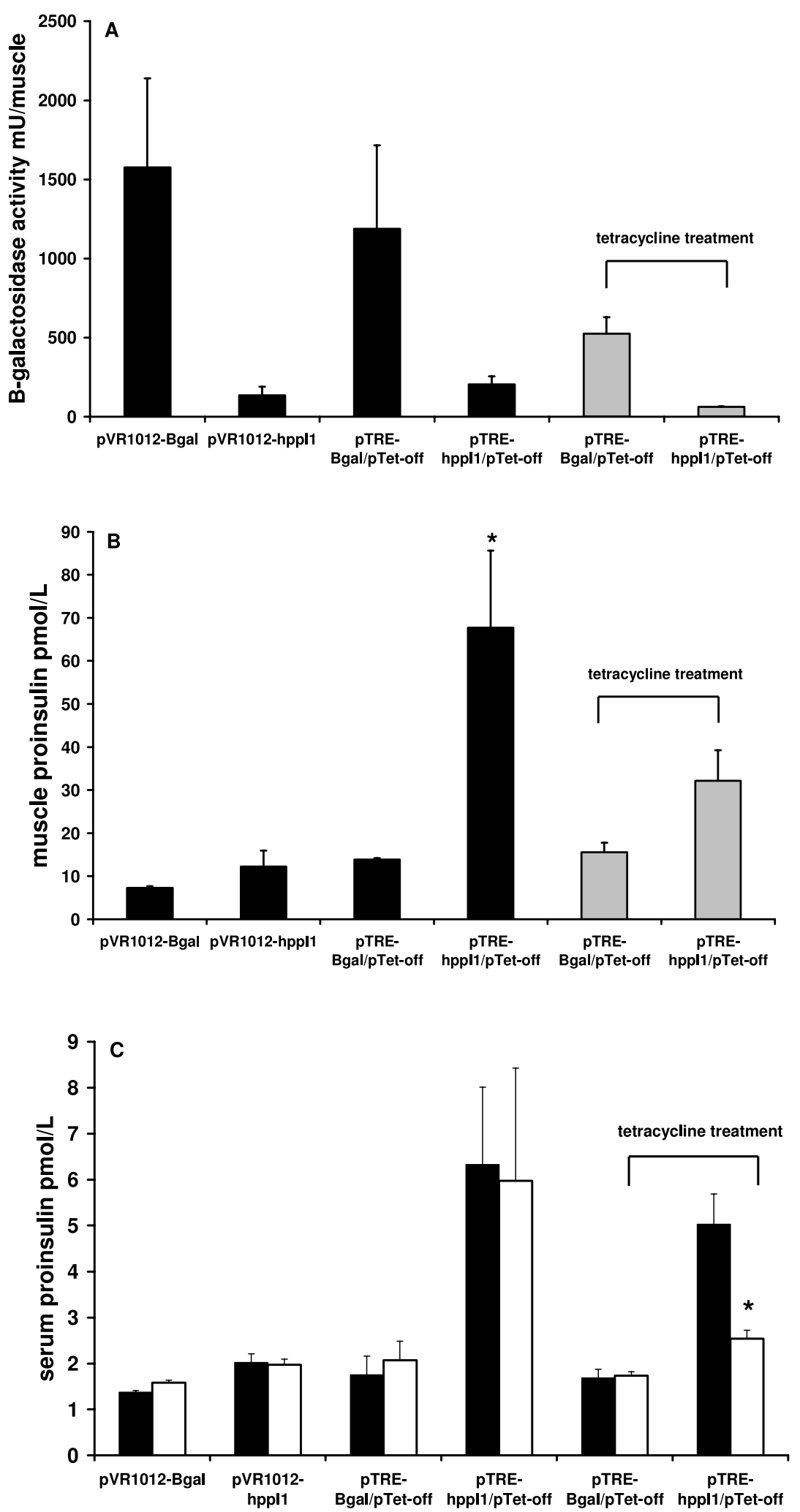
The feasibility of regulating transgene transcription and thus human proinsulin secretion in transfected human myoblasts has been confirmed in the present studies employing a tetracycline-responsive wild type insulin construct in combination with the safe and well-tolerated but infrequently used antibiotic, tetracycline. Acting at the level of transgene transcription, the effects of tetracycline administration were manifest incrementally over a 48- to 72-h period in vitro. Dose-responsive repression of proinsulin secretion was demonstrated over a wide concentration range with significant reduction at $24 \mathrm{~h}$ with $1 \mathrm{ng} / \mathrm{ml}$ tetracycline and a nadir at $27 \%$ of levels secreted in untreated human myoblasts on incubation with $1 \mu \mathrm{g} / \mathrm{ml}$ tetracycline for $72 \mathrm{~h}$. In comparison, proinsulin secretion was reduced to $25 \%$ in pTRE-hppI1-transfected C2C12 cells following $72 \mathrm{~h}$ tetracycline incubation at $1 \mu \mathrm{g} / \mathrm{ml}$ and to $13 \%$ with $100 \mu \mathrm{g} / \mathrm{ml}$ tetracycline.

Reversibility of tetracycline effect was confirmed in human myoblasts with proinsulin secretion decreasing to $19 \%$ over $72 \mathrm{~h}$ of incubation with $0 \cdot 1 \mu \mathrm{g} / \mathrm{ml}$ tetracycline and returning to $92 \%$ of that in untreated cells over the subsequent $72 \mathrm{~h}$.

Dose-responsive tetracycline-regulated secretion of fully processed human insulin has been attained in C2C12 cells with significant reduction after $24 \mathrm{~h}$ incubation with $10 \mathrm{pg} / \mathrm{ml}$ tetracycline and repression to $12 \%$ of that in cells cultured in the absence of tetracycline over $48 \mathrm{~h}$ incubation with $100 \mu \mathrm{g} / \mathrm{ml}$ tetracycline.

Expression of a $\beta$-galactosidase reporter gene and wild type human preproinsulin by transfected muscle fibres has been confirmed following a single intramuscular injection of tetracycline-repressible plasmid mixed with the tetracycline-responsive transcriptional activator plasmid and in situ electroporation. Systemic secretion of human proinsulin has been confirmed in normal rats by specific ELISA. Transcriptional repression has been demonstrated following oral tetracycline administration leading to down-regulation of tissue $\beta$-galactosidase and proinsulin expression. Human proinsulin secretion was significantly reduced over a 72-h period. The absence of significant glucose lowering in normal animals was expected due to the reduced bioactivity of proinsulin in comparison with mature insulin, down-regulation of endogenous insulin secretion, and intact hypoglycaemia counter-regulation. Nevertheless, confirmation of stable basal proinsulin secretion which can be regulated without hypoglycaemia provides important proof of the safety of this approach. Further studies are proposed in rodents with chemically induced and autoimmune diabetes prior to consideration of large animal and clinical trials.

We are not aware of other groups exploring regulated insulin secretion following gene transfer to skeletal muscle. An increasing number of systems for small molecule transcriptional regulation are being developed. The tetracycline-responsive system is particularly attractive for therapeutic implementation given the proven safety of the antibiotic small molecule regulator when delivered orally, with no evidence for toxicity of the tetracycline-responsive or transactivator plasmid in in vitro or in vivo studies. A further benefit of a regulatory system derived from prokaryotic cells is absence of interference with transcriptional control in a eukaryotic host cell. The tetracycline-repressible system is particularly favoured, as an overdose of tetracycline will effectively 'switch off' the system as opposed to risking excess insulin secretion and prolonged hypoglycaemia. A mechanism for 'switching off' insulin secretion will be critical for safe clinical implementation. The present studies demonstrate efficacy without toxicity in human muscle cells established in culture and in short-term in vivo studies. Longer term studies will be required to preclude loss of transgene expression due to an immune response against bacterial components of the plasmids and specifically the tetracycline-responsive transactivator prior to consideration of clinical trials involving in situ gene transfer to muscle of tetracycline-responsive plasmids for regulated therapeutic protein secretion.

These studies provide proof of principle for establishing and characterising primary human muscle cells in pure primary culture, ex vivo transfection with one or more plasmids, in vitro characterisation, and reimplantation for regulated protein secretion by simple intramuscular injection. This approach enables full in vitro characterisation and selection of cells fulfilling optimised requirements prior to transplantation, avoids the need

\footnotetext{
Figure 7 Expression of tetracycline-responsive and constitutive reporter and wild type preproinsulin plasmids following percutaneous tibialis anterior injection and in situ electroporation. In the absence of tetracycline, muscle $\beta$-galactosidase activity at day 7 post-plasmid injection was not significantly different in pVR1012- $\beta$ gal and pTRE- $\beta$ gal/pTet-off injected groups but was greater than in control preproinsulin plasmid-injected groups (A: solid bars; means \pm S.E.M.; $n=3$ ). Following $1 \mathrm{mg} / \mathrm{ml}$ tetracycline treatment for $72 \mathrm{~h}$, reduced $\beta$-galactosidase activity in the pTRE- $\beta$ gal/pTet-off group was confirmed (A: grey bars; means $\pm S$.E.M.; $n=4)$. In the absence of tetracycline, muscle human proinsulin biosynthesis at day 7 was significantly higher in the pTRE-hppl1/pTet-off group compared with the pVR1012-hppl1 and $\beta$-galactosidase control groups (B: solid bars; means \pm S.E.M.; $n=3 ;{ }^{*} P<0.05$ ). Following $1 \mathrm{mg} / \mathrm{ml}$ tetracycline treatment for $72 \mathrm{~h}$, reduced proinsulin biosynthesis in pTRE-hppl1/pTet-off group was confirmed (B: grey bars; means \pm S.E.M., $n=4)$. In the absence of tetracycline, muscle human proinsulin secretion was higher in the pTRE-hppl1/pTet-off group compared with the pVR1012-hppl1 and $\beta$-galactosidase control groups at day 4 (C: solid bars) and day 7 (C: open bars). Tetracycline $(1 \mathrm{mg} / \mathrm{ml})$ treatment for $72 \mathrm{~h}$ (days $4-7)$ significantly reduced proinsulin secretion in the pTRE-hppl1/pTet-off group $\left({ }^{*} P<0.05\right)$.
} 
for immunosuppression in keeping with in vivo gene delivery, and further minimises the risk of transgene dissemination and oncogenesis.

The importance of achieving sustained and constant background insulin replacement in both Type 1 and insulin-treated Type 2 diabetes is becoming increasingly apparent. All long-acting insulin preparations including novel analogues are associated with ongoing risk of significant hypoglycaemia due to inappropriate peaks and troughs in insulin action over a 24-h period (Owens et al. 2001). Proof of concept for minimising hypoglycaemia risk through constant background insulin replacement with infrequent adjustments in this 'basal rate' to accommodate illness, weight changes and major alterations in diet or exercise is provided from continuous subcutaneous insulin infusion pump therapy. Muscle-targeted tetracycline-responsive insulin gene therapy offers the potential of sustained background insulin replacement with tetracycline administered in divided doses to achieve a stable plasma concentration. Background insulin level would be titrated in the light of fasting and late post-prandial glucose concentrations by altering the dose of tetracycline to achieve a new stable plasma concentration. Basal insulin replacement in combination with oral hypoglycaemic agents has been shown to be safe and effective in Type 2 diabetes (Riddle et al. 2003). Prandial short-acting insulin injections would be required in Type 1 diabetes. Ultimately, a single plasmid-based system mediating conditional aggregation of proinsulin within the endoplasmic reticulum enabling rapid secretion in non-endocrine cells following oral administration of a disaggregation ligand offers the potential of replacing pre-prandial bolus insulin injections also with muscle-targeted insulin gene therapy (Rivera et al. 2000). We believe that these approaches may be of particular benefit to companion cats and dogs with diabetes in whom control with conventional therapy often remains very poor.

In conclusion, proof of concept for biosynthesis, post-translational processing and regulated secretion of a human therapeutic protein in human muscle in vitro in addition to rat muscle in vivo has been attained employing plasmid-mediated transfection in conjunction with the non-toxic and well-tolerated antibiotic, tetracycline. Potential future clinical gene therapy applications include diabetes mellitus in addition to a very wide range of endocrine, haematological and other disorders characterised by isolated circulating protein deficiency.

\section{Acknowledgements}

M O W was supported by a Nigerian governmentfunded $\mathrm{PhD}$ scholarship. K T S was supported by the University of Newcastle and the Wellcome Trust.
J A M S was supported by an unrestricted Glaxo-SmithKline Senior Clinical Fellowship. We wish to thank Prof. Kevin Docherty for provision of hppIl and hppI4 cDNAs in addition to Prof. S J Yeaman and Prof. M Walker for provision of human myoblast samples.

\section{References}

Abai AM, Hobart PM \& Barnhart KM 1999 Insulin delivery with plasmid DNA. Human Gene Therapy 10 2637-2649.

Belles-Isles M, Roy R, Dansereau G, Goulet M, Roy B, Bouchard JP \& Tremblay JP 1993 Rapid selection of donor myoblast clones for muscular dystrophy therapy using cell surface expression of NCAM. European Fournal of Histochemistry 37 375-380.

Blau HM \& Webster C 1981 Isolation and characterization of human muscle cells. PNAS 78 5623-5627.

Croze F \& Prud'homme GJ 2003 Gene therapy of streptozotocin-induced diabetes by intramuscular delivery of modified preproinsulin genes foumal of Gene Medicine $\mathbf{5}$ 425-437.

Diabetes Control and Complications Trial Research Group 1993 The effect of intensive treatment of diabetes on the development and progression of long-term complications in insulin-dependent diabetes mellitus. New England fournal of Medicine 329 977-986.

Fiorina P, La Rocca E, Venturini M, Minicucci F, Fermo I, Paroni R, Angelo A Sblendido M, Carlo VD, Cristallo M, Maschio AD, Pozza G \& Secchi A 2001 Effects of kidney-pancreas transplantation on atherosclerotic risk factors and endothelial function in patients with uremia and Type 1 diabetes. Diabetes $\mathbf{5 0}$ $496-501$

Gene Therapy Clinical Trials online database (www.wiley.co.uk./ genetherapy) accessed 23:04.04.

Halse R, Rochford JJ, McCormack JG, Vandenheede JR, Hemmings BA \& Yeaman SJ 1999 Control of glycogen synthesis in cultured human muscle cells. Foumal of Biological Chemistry 274 776-780.

Hartikka J, Sawdey M, Cornefert-Jensen F, Margalith M, Barnhart K, Nolasco M, Vahlsing HL, Meek J, Marquet M, Hobart P, Norman J \& Manthorpe M 1996 An improved plasmid DNA expression vector for direct injection into skeletal muscle. Human Gene Therapy 7 1205-1217.

Hay CW \& Docherty K 2003 Enhanced expression of a furin-cleavable proinsulin. Fournal of Molecular Endocrinology $\mathbf{3 1}$ 597-607.

Horton HM, Anderson D, Hernandez P \& Barnhart KM 1999 A gene therapy for cancer using intramuscular injection of plasmid DNA encoding interferon alpha. PNAS 96 $1553-1558$

Kawakami Y, Yamaoka T, Hirochika R, Yamashita K, Itakura M \& Nakauchi H 1992 Somatic gene therapy for diabetes with an immunological safety system for complete removal of transplanted cells. Diabetes 41 956-961.

Kleinman HK, McGarvey ML, Liotta LA, Robey PG, Trygvasson K \& Martin GR 1982 Isolation and characterization of type IV procollagen, laminin and heparan sulfate proteoglycan from the EHS sacroma. Biochemistry 24 6188-6193.

Kon OL, Sivakumar S, Teoh KL, Lok SH \& Long YC 1999 Naked plasmid-mediated gene transfer to skeletal muscle ameliorates diabetes mellitus. Fournal of Gene Medicine 1 186-194.

Martinenghi S, Cusella De Angelis G, Biressi S, Amadio S, Bifari F, Roncarolo MG, Bordignon C \& Falqui L 2002 Human insulin production and amelioration of diabetes in mice by electrotransfer-enhanced plasmid DNA gene transfer to the skeletal muscle. Gene Therapy 9 1429-1437. 
Owens DR, Zinman B \& Bolli GB 2001 Insulins today and beyond. Lancet 358 739-746.

Rees S, Coote J, Stables J, Goodson S, Harris S \& Lee MG 1996 Bicistronic vector for the creation of stable mammalian cell lines that predisposes all antibiotics-resistant cells to express recombinant protein. BioTechniques 20 102-110.

Riddle MC, Rosenstock J \& Gerich J 2003 The treat-to-target trial: randomized addition of glargine or human NPH insulin to oral therapy of type 2 diabetic patients. Diabetes Care $\mathbf{2 6}$ 3080-3086.

Rivera VM, Wang X, Wardwell S, Courage NL, Volchuk A, Keenan T, Holt DA, Gilman M, Orci L, Cerasoli F Jr, Rothman JE \& Clackson T 2000 Regulation of protein secretion through controlled aggregation in the endoplasmic reticulum. Science $\mathbf{2 8 7}$ 826-830.

Ryan EA, Lakey JRT \& Paty BW 2002 Successful islet transplantation: continued insulin reserve provides long-term glycemic control. Diabetes 51 2148-2157.

Scougall KT \& Shaw JAM 2003 Tetracycline-regulated secretion of human insulin in transfected primary myoblasts. Biochemical and Biophysical Research Communications 304 167-175.

Scougall KT, Maltin CA \& Shaw JM 2003 Tetracycline-regulated secretion of human insulin in transfected non-endocrine cell line. Fournal of Molecular Endocrinology 30 331-346.

Shaw JAM \& Docherty K 2002 Genetic engineering in the treatment of diabetes. In Oxford Textbook of Endocrinology and Diabetes, pp 1866-1872. Eds J Wass \& S Shalet. Oxford, UK: Oxford University Press.
Shaw JAM, Delday MI, Hart AW \& Docherty K 2002 Secretion of bioactive human insulin following plasmid-mediated gene transfer to non-neuroendocrine cell lines, primary cultures, and rat skeletal muscle in vivo. Fournal of Endocrinology 72 653-672.

Simonson GD, Groskreutz DJ, Gorman CM \& MacDonald MJ 1996 Synthesis and processing of genetically modified human proinsulin by rat myoblast primary cultures. Human Gene Therapy $\mathbf{7}$ 71-78.

Tripathy SK, Svensson EC, Black HB, Goldwasser E, Margalith M., Hobart PM \& Leiden JM 1996 Long-term expression of erythropoietin in the systemic circulation of mice after intramuscular injection of a plasmid DNA vector. PNAS 93 10876-10880.

UK Prospective Diabetes Study Group 1998 Intensive blood-glucose control with sulphonylureas or insulin compared with conventional treatment and risk of complications in patients with Type 2 diabetes. Lancet 352 837-853.

Wolff JA, Ludtke JJ, Acsadi G, Williams P \& Jani A 1992 Long-term persistence of plasmid DNA and foreign gene expression in mouse muscle. Human Molecular Genetics 1 363-369.

Yamasaki K, Takashi S, Nemoto M, Eto Y \& Tajima N 1999 Differentiation-induced insulin secretion from nonendocrine cells with engineered human proinsulin cDNA. Biochemical and Biophysical Research Communications 265 361-365.

Received 26 November 2004 Accepted 6 December 2004 